\title{
Long-term experiments in the South Island high country: an example from Mt. Possession, Canterbury
}

\author{
KRISTÍN SVAVARSDÓTTIR ${ }^{1}$, J.G.H. WHITE and J.G. PALMER
} Plant Science Department, PO Box 84, Lincoln University

\section{Abstract}

This paper discusses the successional changes that have occurred during 13 years of a designed experiment in short tussock grassland. The 'experiment site is at Mt. Possession Station, Canterbury and was established in 1979. Nine species of legume were overdrilled and 9 phosphate rates $(\mathrm{O}-800 \mathrm{~kg} \mathrm{P} / \mathrm{ha})$ broadcast at sowing. A vegetation survey of all plots was carried out in November 1991 and soil sampled in the following year. Legumes were dominant during the early years of the experiment but the responses to $\mathrm{P}$ rates differed. Some of the differences in the present vegetation could be explained by earlier treatment effects. Exotic grasses invaded the plots which received higher levels of fertiliser with the exception of plots sown with Lupinus species where grass growth was independent of the applied $\mathrm{P}$ rate. The initial treatments have strongly affected present vegetation. Had an attempt been made at the beginning to predict the current composition, or even half way through the experiment, the conclusions are unlikely to have been realistic. It is suggested that the dynamics and composition of

- the_responses-are-inter-related-and-complex,-andas such, they require long-term monitoring before any predictions can be made.

Keywords: long-term experiment, phosphate gradient, sown legumes, species composition, tussock grasslands

\section{Introduction}

The increasing abundance of Hieracium spp. in the -native tussock grasslands of the South Island (Hunter 1991; Treskonova 1991a; Hunter et al. 1992) has been ascribed to the degradation of these ecosystems (Treskonova 1991a, 1991b). One aspect of a degraded ecosystem is depletion in soil fertility. This has been modelled in tussock grasslands (O'Connor \& Harris 1991) but little attempt has been made to investigate the effect of soil fertility on species composition in a community. A better understanding of this relationship

Miss E.L. Hellaby Indigenous Grasslands Research Fellow could assist in assessing the stage of vegetation decline.

The objective of this paper is to give an example of long-term effects of fertiliser application on species composition in a high country experiment and demonstrate how such results might be useful for management.

\section{M ethods}

\section{Site description}

The study site was an existing experiment at Mt. Possession Station, Canterbury, established in short tussock grassland by the Forest Research Institute in 1979. It is located in the lake district of the upper Ashburton at an altitude of $680 \mathrm{~m}$ with a mean annual rainfall of $870 \mathrm{~mm}$ (Thompson 1985). The soil belongs to the Pukaki series of the yellow-brown earths. The experimental area was fenced from livestock and had not been cultivated or fertilised before the experiment was set up (Davis 1991). The initial aim of the experiment was to compare the performance of a range of legumes that were known to vary in edaphic adaptation along a phosphate gradient (Davis 1991). Nine species of legume were overdrilled, together with a non-legume control, and 9 phosphate $(\mathrm{P})$ rates brōadcast a sowing as superphosphate (Table 1). Altogether there were 90 treatments, each replicated 4 times. All plots were $2.3 \times 4 \mathrm{~m}$ in size and they received a basal application of magnesium, potassium, sulphur and molybdenum. Since 1979 no further fertiliser applications have been made. Four new plots were established in the summer of 1991192 within the exclosure but in an untreated area to act as indicators of natural succession which had occurred since the area was excluded from stock.

Table 1 Initial treatments at Mt. Possession.

\begin{tabular}{lc}
\hline Sown legumes: & $\begin{array}{c}\text { Phosphorus rate } \\
\text { (kg P/ha) }\end{array}$ \\
\hline Trifolium repens (Grasslands Huia) & 0 \\
Trifolium pratense (Grasslands Pawera) & 6.25 \\
Trifolium hybridum (Terra) & 12.5 \\
Trifolium ambiguum (Prairie) & 25 \\
Medicago sativa (Wairau) & 50 \\
Lotus comiculatus (hlaitland) & 100 \\
Lotus pedunculatus (Grasslands Maku) & 200 \\
Lupinus arboreus & 400 \\
Lupinus polyphyllus & 800 \\
Fertiliser only & \\
\hline
\end{tabular}




\section{Data gathering}

The species present were recorded, together with their abundance using the Braun-Blanquet scale ( $\boldsymbol{r}=\mathbf{r a r e}$, one or few individuals; $+=0$ ccasional plants. cover $1 \%$; $1=$ cover $1.5 \% ; 2=6-25 \% ; 3=26-50 \% ; 4=51-75 \% ; 5=76$ $100 \%$; Westhoff \& van der Maarel 1978). The vegetation cover was estimated in November 1991.

There was the concern that planted trees could have affected the species composition in some plots and consequently these were deleted from the data set. Ten soil cores to $15 \mathrm{~cm}$ depth were taken from each plot. The 10 cores were bulked, air dried at $25^{\circ} \mathrm{C}$ and sieved through a $2 \mathrm{~mm}$ sieve. Soil total $\mathrm{P}$, inorganic $\mathrm{P}$, organic $\mathrm{P}, \mathrm{pH}$ (Blakemore et al. 1987) total nitrogen $(\mathrm{N})$ and total carbon (C) (Goh pers. comm.) were analysed.

\section{Data analysis}

Because of the number of variables in the data set, multivariate analyses were chosen. The species data were first studied by applying correspondence analysis (CA) to investigate the distributional pattern of the data set (based on the midpoints of the cover values of the Braun-Blanquet scores). Results and patterns observed from the $\mathrm{CA}$ tables implied that the species response curves to their environment were bell-shaped and therefore it was acceptable to use unimodular methods. The next step was the use of canonical correspondence analysis (CCA) which was applied on the data set using treatments and measured soil components as environ-mental variables. Replicates were used as covariables for excluding the variance, if any, between them. The analyses were carried out using the program CANOCO version 3.1 (ter Braak 1988 and 1990). The soil data were also analysed by analysis of variance (ANOVA) using SAS, version 6.07 (Sas Institute Inc. 1990).

\section{Results}

Results of the two ordination techniques show a differentiation in species composition along a fertility gradient. Eigenvalues in ordination indicate the variance in the analysed data set which the relevant axis explains and in general the higher the eigenvalue, the more important is the axis (ter Braak 1988). An eigenvalue is also a measure of dispersion of the variables (e.g. species) along the ordination axis (Jongman et al. 1987). In this study the first two axes explained most of the variance in the species composition for both types of analyses (First axis: 0.56, 0.39; second axis: $0.49,0.34$; third axis: 0.30 , 0.17; fourth axis: $0.24,0.10$; for CA and CAA respectively). Having ranked the plot and species scores obtained for the first ordination axis in CA, a pattern was observed. Plots that received low or nil superphosphate received lowest CA scores and plots with high $\mathrm{P}$ rate received the highest scores. Since the spread of the plots along the first two axes indicated some kind of fertility gradient a Spear-man correlation coefficient was calculated for the plot scores of the first axis and applied $P$ rate giving overall $r_{s}=0.67$ $(\mathbf{P}<0.001)$. This was consistent with the results from CCA in which the first ordination axis was determined mainly by the applied fertiliser and soil $\mathrm{P}$ with additional contribution fromLupinus spp. and untreated plots (Figure 1). The second axis was strongly linked to sown Trifolium ambiguum. Plots with $T$. ambiguum differed from those containing other legumes in the way that T. ambiguum was still dominant in the highest $\mathrm{P}$ rate, excluding most other species. The only other legume that was found dominant in any plot was Lupinus polyphyllus that had also invaded many plots of other legume treatments over time. The general pattern was that the number of species decreased with increasing fertility and native species mostly disappeared at the highest fertility. The largest differences were between plots that received $12.5 \mathrm{~kg}$ $\mathrm{P} / \mathrm{ha}$ and those that received $200 \mathrm{~kg} \mathrm{P} / \mathrm{ha}$ or more ( $\mathrm{P}<0.05)$. Species richness also differed between sown legumes. While all the clovers showed similar results the plots that contrasted were those that had $L$. polyphyllus. The lupin plots had fewer species along the whole $\mathrm{P}$ gradient than any other legume and only few native species grew there.

Of the measured soil components inorganic $\mathrm{P}$ had the most influence on species composition $\left(\mathrm{r}^{2}=0.75\right.$ in correlation with the first environmental axis, $\mathbf{P}<0.001$ ) and also positively correlated with applied $\mathrm{P}$ rate (rk0.89, $\mathrm{P}<0.001$; meaning that the more $\mathrm{P}$ applied in 1979 the higher the soil inorganic $P$ in 1992). Inorganic soil $\mathrm{P}$ was the soil component that varied most between applied $\mathrm{P}$ levels $(\mathrm{P}<0.001$ in ANOVA, Table 2$)$. Soil $\mathrm{pH}$ averaged $5.84, \% \mathrm{~N} 0.52, \% \mathrm{C} 7.31$ and $\mathrm{C} / \mathrm{N}$ ratio 13.95. They explained very little of the species variation even though their trends were informative.

\section{Discussion}

The superphosphate applied in 1979 has had the most effect in determining the species composition in 1991 although some legumes also contributed to the picture. During the first few years of the experiment the vegetation went through a legume-dominant stage (Davis 1991). All legumes responded to superphosphate except the Lupinus spp. which had high production throughout the $\mathrm{P}$ gradient because of its known ability to grow on soils low in available P (Davis 1981). 
Figure 1 Treatments and soil components for first and second axes of canonical correspondence analysis (CCA) ordination for the Mt. Possession experiment in 1991192. Legume treatments and the untreated area are considered as nominal variables and shown as filled squares while the quantitative variables are displayed with vectors. Three species are displayed with dots: $\mathbf{A}$ odo $=$ Anthoxanthum odoratum, $\mathbf{A}$ cup $=$ Agrostis capillaris, Ppra $=$ Poa pratensis.

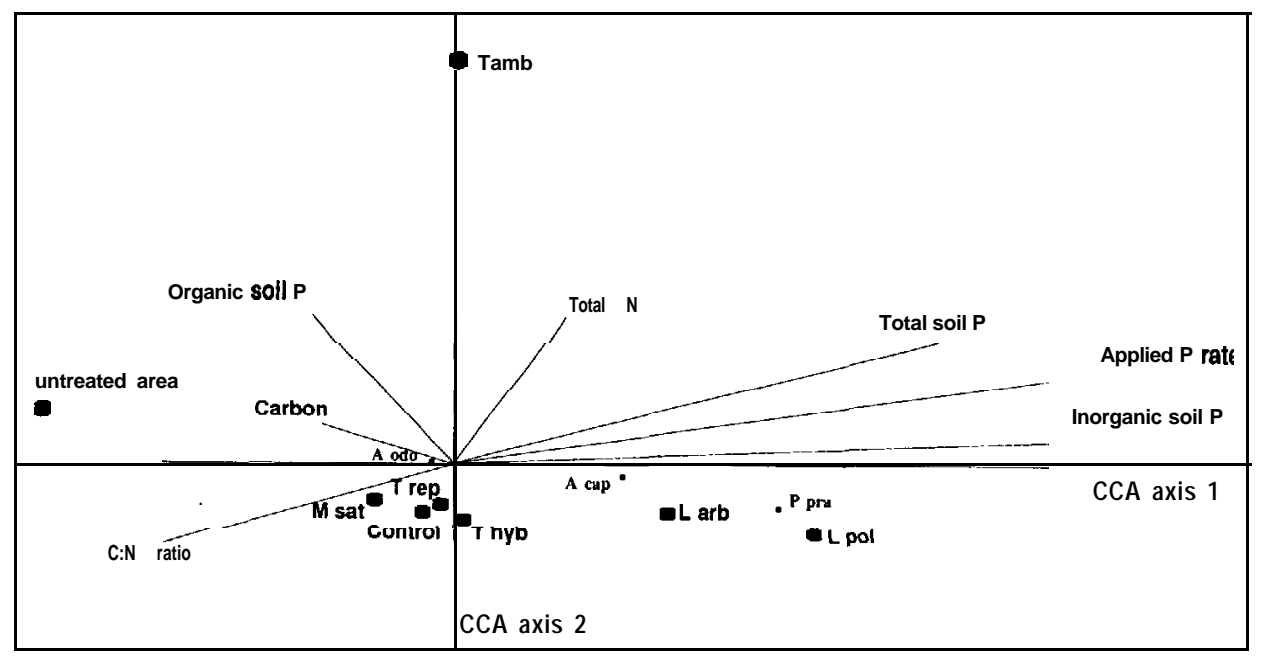

Table 2 The effect of $\mathrm{P}$ applied in 1979 on total, inorganic and organic soil $\mathrm{P}$ levels at Mt. Possession in 1992.

\begin{tabular}{|c|c|c|c|c|c|}
\hline$P$ rate & Sample & $\#$ & $\begin{array}{l}P_{\text {total }} \\
\text { ppmin }\end{array}$ & $\begin{array}{c}P_{\text {Inorganic }} \\
\text { Ppin }\end{array}$ & $\begin{array}{c}P_{\text {organic }} \\
\text { ppm }\end{array}$ \\
\hline 6.25 & 21 & & 796 & 77 & 719 \\
\hline 12.5 & 29 & & 672 & 65 & 767 \\
\hline 25 & 30 & & 796 & 99 & 697 \\
\hline 50 & $\overline{33}-$ & - & 869 & $111 \overline{111}$ & 756 \\
\hline 100 & 21 & & 906 & 123 & 763 \\
\hline 200 & 36 & & 946 & 161 & 766 \\
\hline 400 & 30 & & 1070 & 305 & 765 \\
\hline $\begin{array}{l}600 \\
S E_{\text {max }}\end{array}$ & 39 & & $\begin{array}{c}1350 \\
35.3^{\mathrm{m}}\end{array}$ & $\begin{array}{c}646 \\
26.3^{\mathrm{m}}\end{array}$ & $\begin{array}{c}702 \\
34.6^{\prime}\end{array}$ \\
\hline CV & & & 13 & 41 & 16 \\
\hline
\end{tabular}

Significant levels are indicated with stars. $.=P<0.05, n=P<$ $0.001 .^{1} \mathrm{SE}$ varies between treatments because of the unbalanced design caused by the trees affect. A conservative approach is followed here showing the largest SE for each treatment.

However, there were differences in the response between legumes, with Trifolium spp. (except $T$. ambiguum) being much more productive than any of the other pasture legumes after one growing season. This changed slightly in the second season with relatively greater increases in productivity of Lotus corniculatus and T. ambiguum than any of the other species (Davis 1991). Grass invasion into plots was recorded as early as 1981 after a dry summer (Davis 1991). The introduced grasses most commonly found in 1991 when ranked along the applied P gradient (the ranking is also valid for inorganic soil $\mathrm{P}$ ) were $\mathbf{P o a}$ pratensis at the highest rates, followed by Agrostis capillaris and Anthoxanthum odoratum (Figure 1). Little grass (mainly A, odoratum) occurred in the lowest $\mathrm{P}$ rate where $\mathbf{H}$ ieracium pilosel la was a dominant species.

All of the legumes were still in the experiment 13 years-after the-establishment-but-their-frequency-variedgreatly and only $\mathbf{L}$. polyphyllus and $\mathbf{T}$. ambiguum were found in any abundance. Species composition differed between these two legume treatments and they were also distinct from any other species treatment (Figure 1). The distinctive position of $\boldsymbol{T}$. ambiguum treatment in Figure 1 is suggested to be due to its dominance in the highest $P$ rates whereas other species are mostly excluded. This is probably caused by the enormous below-ground biomass (15-20 t/ha) that has been observed under these conditions (Strachan et al. 1994). Vigorous grass growth occurred in all plots with sown L. polyphyllus, and its location in Figure 1 suggests that the legume simulates high $\mathrm{P}$ rate plots. Only a few native plants grew under these conditions of tall legume and grass growth.

This research demonstrates that we are able to change the soil fertility with sown legumes and superphosphate and hence affect vegetation composition. These effects on vegetation composition do not occur all at the one time, but occur as a series of changes initiated by the combination of treatments at the outset, and expressed as diverging outcomes while 
potentially complicating influences were excluded. Management treatments applied at the beginning, whether in an experiment or in farm practice, may influence the present condition of vegetation far more than current management treatments (O'Connor \& Harris 1991). This stresses the need to set clear objectives for each occasion since management options differ depending on them. There would for instance be different approaches to achieve native species conservation than for productivity.

\section{ACKNOWLEDGEMENTS}

We thank sue Thomson and Sandy Hines for their field assistance, Leo Condron for guidance with soil analyses, George Love for help with statistical analyses and Alan Nordmeyer of FRI for help and advice throughout this work. Thanks to Kevin O'Connor for his comments on the paper and to John Whyte of Mt.Possession Station for use of his land.

\section{REFERENCES}

Blakemore, L.C.; Searle, P.L.; Daly, B.K. 1987. Methods for chemical analysis of soils. New Zealand Soil Bureau, Scientific Report 80.

Davis, M.R. 1981. Growth and nutrition of legumes on a high country yellow-brown earth subsoil. I. Phosphate response of Lotus, Trifolium, Lupinus, Astragalus, and Coronilla species and cultivars. New Zealand journal of agricultural research 24: 321-332

Davis, M.R. 1991. The comparative phosphorus requirements of some temperate perennial legumes. Plant and soil 133: 17-30.

Jongman, R.H.G.; ter Braak, C.J.F.; van Tongeren, O.F.R. 1987. Data analysis in community and landscape ecology. Pudoc, Wageningen.

Hunter, G.G. 1991. The distribution of hawkweeds (Hieracium spp.) in the South Island, indicating problem status. Journal of the New Zealand Mountain Lands Institute, review 48: 21-31.
Hunter, G.G.; Mason, C.R.; Robertson, D.M. (Eds), 1992. Vegetation change in tussock grasslands, with emphasis on hawkweeds. Occasional Publication No.2, New Zealand Ecological Society, Christchurch.

O’Connor, K.F.; Harris, P.S. 1991. Biophysical and cultural factors affecting the sustainability of high country pastoral land uses. The proceedings of the international conference on sustainable land management: $304-313$.

SAS Institute Inc. 1990. SAS/STAT User's Guide, Version 6, Fourth Edition, Volume 2. Cary, NC:SAS Institute Inc., $846 \mathrm{pp}$.

Strachan, D.; Nordmeyer, A.H.; White, J.G.H. 1994. Nutrient storage in roots of hexaploid Caucasian clover. Proceedings of the New Zealand Grassland Association 56: (this volume).

ter Braak, C.J.F. 1988. CANOCO -, a FORTRAN program for canonical community ordination by correspondence analysis, principal components analysis and redundancy analysis (Version 2.1), Technical Report: LWA-88-02, Agricultural Mathematics Group, Wageningen. 95 pp.

ter Braak, C.J.F. 1990. Updated notes: CANOCO version 3.10. Agricultural Mathematics Group, Wageningen. $35 \mathrm{pp}$.

Thompson, C.S. 1985. Maps of rainfall parameters for New Zealand. NZ meteorological service misc publication 187. New Zealand Meteorological Service, Ministry of Transport.

Treskonova, M. 1991 a. Changes in the structure of tall tussock grasslands and infestation by species of Hieracium in the Mackenzie Country, New Zealand. New Zealand journal of ecology 15: 65-78.

Treskonova, M. 1991b. Hieracium - an ecological perspective. Journal of the New Zealand Mountain Lands Institute, review 48: 32-40.

Westhoff, V.; van der Maarel, E. 1978. The BraunBlanquet approach. pp. 287-399 In Classification of Plant Communities. Whittaker, R.H. (ed.), Junk, The Hague. 